\section{PHYSICAL GEOGRAPHY AND TERRESTRIAL MOLLUSCA OF THE BAHAMA ISLANDS}

A PAPER on this subject has recently been communicated to the Lyceum of Natural History, New York, by Mr. Thomas Bland.

The northern end of the Bahama group lies opposite southern Florida, and from this point the islands stretch off in a double series, nearly parallel to the trend of Cuba and San Domingo, and terminate, properly, in the Turk's Island Bank, on which are the last and most easterly of the chain, which extends about 600 miles, from within 70 miles of the coast of Florida to within roo miles of that of San Domingo.

Several banks are distinguishable, and the islands are generally on the windward sides of these, never exceeding $200 \mathrm{ft}$. in height, and being almost universally environed with reefs or shelves of rock, which extend often to a considerable distance and usually terminate abruptly.

The geological formation appears to resemble that of Bermuda ; their form and surface condition being largely due to prevailing winds and currents, but also owing much, probably, to the con figuration of the land on which the coral reefs were built up.

Lieutenant Nelson speaks of the Bahamas as the Gulf Stream Delta; thrown down where the stream receives a check from the Atlantic on emerging from the Gulf of Mexico.

In a communication to NATURE, vol. vi. p. $262, \mathrm{Mr}$. Jones furnished evidence of the subsidence of the Bermudas. In excavations made for the great dock e.g., there was found, at $46 \mathrm{ft}$. below low-water mark, a layer of red earth, containing remains of cedar trees, and resting on a bed of compact calcareous sandtone

Mr. Bland examines the evidence afforded (as to subsidence), by the distribution of land shells on the Bahama Islands. The total number of species known is about 80 .

Judging from both operculates and inoperculates, the landshell fauna of the Bahamas is essentially West Indian, and that of the Great Bank (especially), closely allied to the Cuban fauna. Mr. Bland gives a list of inoperculate species common to the Bahamas, the adjacent continent, Bermuda, and certain of the West Indian Islands; which show's in a marked manner the alliance referred to.

The banks and islands of the Bahama chain diminish in size to the south-east, indicating greater subsidence in that direction. Similarly, the submerged Virgin Island bank, Sombrero and the Anguilla bank, terminate the parallel West Indies chain eastward from Cuba ; and in Anguilla have been found remains of large extinct mammalia which must have inhabited at one time a much more extensive area.

The author criticises Dr. Cleve's geological grouping of the slands north of Guadeloupe (in two groups, one comprising Bahamas, of post-pliocene date, another of the tertiary Eocene, Miocene, and Pliocene), and points out that the land shell fauna of Saba, St. Eustatius, St. Kitts and Nevis, of Redonda and Montserrat, and of Barbadoes and Antigua, is, in common with most of the islands to the south, to and inclusive of Trinidad, distinct from the fauna of the islands between and inclusive of the Bahamas and Cuba, and the Anguilla bank, on which are Anguilla, St. Martin and St. Bartholomew. This well-defined line of separation must be considered in connection with the past and present geological history of the islands.

Dana traces parallel bands of greater or less subsidence in the Pacific Ocean, and analogous conditions in the Atlantic; the subsidence was probably, he says, "much greater between Florida and Cuba than in the Peninsula of Florida itself, and greater along the Carribbean Sea parallel with Cuba, as well as along the Bahama reefs than in Cuba." Recent soundings, cited by Mr. Bland, confirm this view.

\section{SCIENTIFIC SERIALS}

Ocean Highways, November.-In an article on "The Results of the Arctic Campaign, 1873 ," it is shown that the right direction for Arctic Exploration has been unmistakeably indicated, further proofs have been afforded of the practicability of attaining an advanced position by following that direction, and additional cvidence has been accumulated against the route advocated by "unpractised theorists." These conclusions are rightly drawn from the eminently successful results obtained from the Polaris expedition and from Captain Markham's fruitful cruise in the Arctic, as contrasted with the comparatively unsuccessful attempts made in the Spitzbergen direction by the Swedish Expe- dition and that of Mr. Leigh Smith. "The learned societies will be able to make their appeal to the Government with even stronger and more cogent arguments than were at their disposal in the end of last year; while in the present Prime Minister and Chancellor of the Exchequer they have an old and staunch supporter of Arctic expeditions, and one who has studied their history and appreciated their uses." There is a carefully constructed map illustrative of Captain Markham's voyage in the Arctic. Other articles are, "On the Distribution of Coal in China," by Baron von Richthofen; "South American Progress" (Argentine Republic), by F. J. Rickard ; "Highways and Bye. ways of Naval History," the first of a series of articles by $\mathrm{Mr}$. $\mathrm{R}$. Lendall.

Gazetta Chimica Italiana, Fascicolo V. and VI.-The number commences with a paper on Santonin, by S. Cannizzaro and F. Sestini. Santoninic acid is described; it is derived from santonin by the addition of one molecule of water to one of santonin. The addition is effected by acting on santonin by means of a warm aqueous alkaline solution. The formula of the acid is $\mathrm{C}_{15} \mathrm{H}_{20} \mathrm{O}_{4^{4}}=\mathrm{C}_{15} \mathrm{H}_{18} \mathrm{O}_{3}+\mathrm{H}_{2} \mathrm{O}$. The properties of the acids and its salts are described, and the action of nascent hydrogen on santonin is then considered. $-\mathrm{New}$ researches on benzylated phenol, by E. Paternò and M. Fileti.-On the chemical analysis of some wines grown in the Veronese province, by Prof. G. Dal Sie. The wines in question seem to be somewhat strong, the percentage (volume) of alcohol ranging from 9.4 to 16.4 . Very voluminous tables of analyses are given.-A paper on the dry distillation of calcic formate, by A. Lieben and E. Paterno concludes the original portion of the number, which concludes with 155 pages of abstracts from foreign journals.

Annalen der Chemie und Pharnacie, Band 168, Heft 2 and 3 , August 30. - The number commences with two papers from Prof. Beilstein's laboratory. The first by W. Hemelian is on a new method of preparing the sulpho acids ; the method in question is a modification of that of Strecker. Dr. E. Wroblevsky communicates a paper on certain haloid derivatives of toluol; he describes a number of the meta-brom-toluol compounds, and also deals with the para-brom-toluols and the tri-brom-toluols. The other papers are : On selenic acid and its salts, by Dr. v Gerichten. He finds that the seleniates are all isomorphous with the corresponding sulphates, and the double salts also agree with the double sulphates. - On the action of tri-sulpho-carbonate and sulpho-carbaminate of ammonium on aldehyde and acetone, by E. Mulder. A number of the compounds resulting from these reactions are described.-. On a new mode of forming ortho toluilic acid, by R. Fittig and William Ramsay. On metatoluic acid, by C. Boettinger and W. Ramsay.--On ethyl and di-ethyl-allyamine, by A. Rinne. Ethyl-allylamine is isomeric with methyl crotonylamine, the two bodies having the formulæ-

$$
\mathrm{N}\left\{\begin{array} { l } 
{ \mathrm { C } _ { 3 } \mathrm { H } _ { 5 } } \\
{ \mathrm { C } _ { 2 } \mathrm { H } _ { 5 } } \\
{ \mathrm { H } }
\end{array} \text { and } \mathrm { N } \left\{\begin{array}{l}
\mathrm{C}_{4} \mathrm{H}_{7} \\
\mathrm{CH}_{3} \\
\mathrm{H}
\end{array}\right.\right. \text { respectively. }
$$

The author describes several of the salts of the former. Di-ethyl. allylamine $\mathrm{N}\left\{\begin{array}{l}\mathrm{C}_{3} \mathrm{H}_{5} \\ \mathrm{C}_{2} \mathrm{H}_{5} \\ \mathrm{C}_{2} \mathrm{H}_{5}\end{array}\right.$ is produced by the action of ethyl iodide on allylamine. The author describes it and its hydrochlorate and platino-chloride.--Researches on the isomers of cresol with regard to their occurrence in coal tar, by M. S. South worth. - Researches on sorbic acid by $\mathrm{E}$. Kachel and $\mathrm{R}$. Fittig.-The number concludes with a very lengthy paper on the actions occurring in the inner non-luminous flame of the Bunsen burner, by R. Blochmann. The author has collected and examined the gases from various parts of the flame, and the memoir is illustrated with two plates showing the apparatus used, and the flames given by the burner under various treatments, and a diagram showing the percentages of $\mathrm{CO}_{2}$ and $\mathrm{H}_{2} \mathrm{O}$, given by fiames when burning, at various heights above the burner up to I20 millimetres.

\section{SOCIETIES AND ACADEMIES}

\section{LONDON}

Zoological Society, Nov. 4.--Prof. Newton, F.R.S., vicepresident, in the chair. The Secretary read a report on the ad ditions that had been made to the Society's menagerie during the months of June, July, August, and September. Mr. G. Dawson Rowley exhibited a singular malformed variety of the Domestic Duck, and the Secretary a collection of fishes (containing six examples of Ceratodus forsteri) made by $\mathrm{Mr}$. 